\title{
LONG-RUN MONEY AND INFLATION NEUTRALITY TEST IN INDONESIA
}

\author{
Arintoko $^{1}$
}

\begin{abstract}
This paper investigates long-run neutrality of money and inflation in Indonesia, with due consideration to the order of integration, exogeneity, and cointegration of the money stock-real output and the money stock-price, using annual time-series data. The Fisher-Seater methodology is used to do the task in this research. The empirical results indicate that evidence rejected the long-run neutrality of money (both defined as M1 and M2) with respect to real GDP, showing that it is inconsistent with the classical and neoclassical economics. However, the positive link between the money and price in long run holds for money defined as M1 rather than M2, which consistent with these theories. In particular, besides the positive effect to long-run inflation, monetary expansions have long-run positive effect on real output in the Indonesian economy.
\end{abstract}

JEL: C32, E31, E51

Keywords: long-run neutrality of money, inflation, unit root, exogeneity, cointegration

1 Lecturer Staff of Faculty of Economic of Jenderal Soedirman University, and a PHD student at Postgraduate Program of Economic Science, UGM. e-mail: arintokoz@yahoo.co.id. 


\section{INTRODUCTION}

The existing money neutrality and the positive correlation between money and price have been very well admitted in economic literature. In classical monetary theory, the change in money supply will affect the nominal variables, but will not affect the real variables because according to classical dichotomy, the power affecting real and nominal variables is different. Nevertheless, it evokes a question that still becomes an interesting issue to economists, whether permanent money supply changes just affect nominal variables without affect the real variables, or whether the money is neutral. Long-run neutrality is considered as something given all this time, where it is just assumption used in economic theory or is a consideration in decision making process, even as a radical assumption. Thus for economist, this money neutrality still becomes a long debate.

According to Lucas (1995) money neutrality is described as situation where changes in money supply will just make changes in nominal variables such as price, nominal exchange rate, and nominal wage without making any changes in real variables such as output, consumption, investment, and employment opportunities, Hume (1752). Furthermore, super neutrality of money is also used, that changes in money supply growth will not cause any changes in real variables in economic unless inflation occurred. Long-run money neutrality hypothesis is mostly based on classical, neoclassic model, or real business cycle theory. Those theories explained that money is neutral in economic and has no affect to real variables, as explained by Hume and Lucas.

Literatures about long-run money neutrality have increased within some last decades. Researches that focus on money neutrality collected many empiric evidences in term of money neutrality proposition; meanwhile some researches focus on testing the existing correlation between money and price in long-run. Some studies about money neutrality are done after the previous research by King and Watson $(1992,1997)$ and Fisher and Seater $(1993)$ in United States. Those kinds of researches then are continued by some experts from South and North America, Australia, Asia including South and South East Asia beside Europe and Africa. Those researches are done by Boschen and Otrok (1994), Olekalns (1996), Haug and Lucas (1997), Serletis and Koustas (1998, 2001), Bae and Ratti (2000), Shelley and Wallace (2003), Noriega (2004), Coe and Nason (2004), Oi et al. (2004), Bae et al. (2005), Noriega and Soria (2005), Noriega et al. (2005), Wallace and Cabrera-Castellanos (2006), Chen (2007), and Puah et al. (2008). Most of this researches adopted Fisher and Seater (1993) and also King and Watson $(1992,1997)$ where some of them did extension. In Asia, among others are Oi et al. (2004) on the case of Japan, Ran (2005) in Hong Kong, Chen (2007) in South Korea and Taiwan, and also Puah et al. for the case of 10 country members of South East Asian Central Banks (SEACEN) 
Research and Training Centre. Meanwhile the issue of the existing positive correlation between money and price were collected in the latest studies by Saatcioglu and Korap (2009), Roffia and Zaghini (2007), also Browne and Cronin (2007). The result conform the conclusions from previous researchers such as Lucas (1980), Dwyer and Hafer (1988), Friedman (1992), Barro (1993), McCandless and Weber (1995), Rolnick and Weber (1997), Dewald (1998), Dwyer (1998), Dwyer and Hafer (1999).

The studies in some cases found supporting evidences about the existing money neutrality, but not the money super neutrality. On the long run correlation between money and price, empirical result generally gives the same conclusion about the existence of positive correlation between money and price; even there are some differences in terms of time-series characteristics from data obtained in some countries.

The paper will test the preposition of long-run money neutrality using either M1 or M2 towards real output and price in Indonesia. This research uses annual time series data. Research focusing on this issue is expected to enrich economic literature and studies and also becomes deep consideration for monetary policy maker.

This paper is started with introduction that contains why the research in terms of longrun inflation and money neutrality test is very important for Indonesian. The second part of this paper discusses and reviews the previous research. The third part explains research method about Fisher-Seater methodology including its prerequisites test such as integration, exogeneity, and cointegration. The forth part provides the result of the research and explanation that will be ended by the fifth part as a conclusion and suggestion.

\section{THEORY}

\subsection{Hume View and Classical Quantitative Theory}

According to money quantitative theory, Hume emphasized the unit change of money stock and its irrelevance towards rational society's behavior. He stated that money is meaningless; however money represents labor and commodity.

There are two Hume's statements that formed a doctrine that a change in money supply stock will have an effect on proportional change towards all prices that reflected in a currency unit and has no effect on real variables like how many people work and how many products manufactured and consumed. Prediction from quantitative theory is that in the long-run the growth money supply is neutral towards the number production growth and influences the inflation proportionally. In a quantity equation from classical quantity theory, 


$$
M x V=P x Y
$$

Where the equation relates money quantity $(\mathrm{M})$ towards nominal output $(\mathrm{P} x \mathrm{Y})$, meanwhile $\mathrm{V}$ shows the velocity of money. The quantity equation shows that the increase of money quantity reflects one of the three other variables, either price increase, output increase, or money velocity decrease, though this velocity tends to be stable all the time. When Central Bank changes money supply, it will cause a proportional change on nominal output ( $\mathrm{P}$ x Y). Because money is neutral according to classical theory, money does not influence the real output, $Y$, but do change the price, $P$.

\subsection{Neoclassical Model}

Theoretical explanation in classical model below is mostly adopted from Barro (1997). This model is started with small opened economic model with four equations assuming the existence of perfect capital mobility assumption.

$$
\begin{aligned}
& E(\stackrel{+}{y}, \bar{r}, \bar{\varepsilon})=y \\
& L(+-\bar{y}, \beta)=(m x B) / P \\
& r=r^{*} \\
& y=y^{*}
\end{aligned}
$$

There are four unknown parameters in real output model $y$, real interest rate $r$, real exchange rate $\varepsilon$, and price $P$. Equation (2) shows equilibrium for goods market in which its demand, $E$ is the function from real income, real interest rate, and real exchange rate. Real exchange rate in this definition is:

$$
\varepsilon=\operatorname{ex}\left(P / P_{f}\right)
$$

where $e$ is nominal exchange rate, $P$ and $P_{f}$ are domestic and foreign price rate respectively. The increase in $\varepsilon$ represents the appreciation of domestic currency that decreases net real export and decreases real goods demand. 
Equation (3) shows equilibrium in money market. Real money demand $L$, is assumed as function of real income $y$, and real interest rate $r$. Variable $\beta$ is an exogenous shock variable. Money supply is Brunner-Meltzer model that consists of money multiplier $m$, and monetary base $B$. Money supply is assumed to be equal with the number of currency in $C$ circulation, added with bank deposits $D$. By dividing nominal money supply with price $P$, it changes money supply into real term. It is assumed that money multiplier is:

$$
m=(1+c) /(r+e+c)
$$

where $c$ is currency ratio towards deposit $(C / D), r$ is minimum required reserve ratio, and $e$ is desired excess reserve ratio. It is assumed that those three variables that determine the money multiplier are exogenous.

From equation (3), it shows that the absence of exogenous in $y^{*}$, and $r^{*}$, or money demand, then real money supply is fixed. This condition generates classical money neutrality which is a

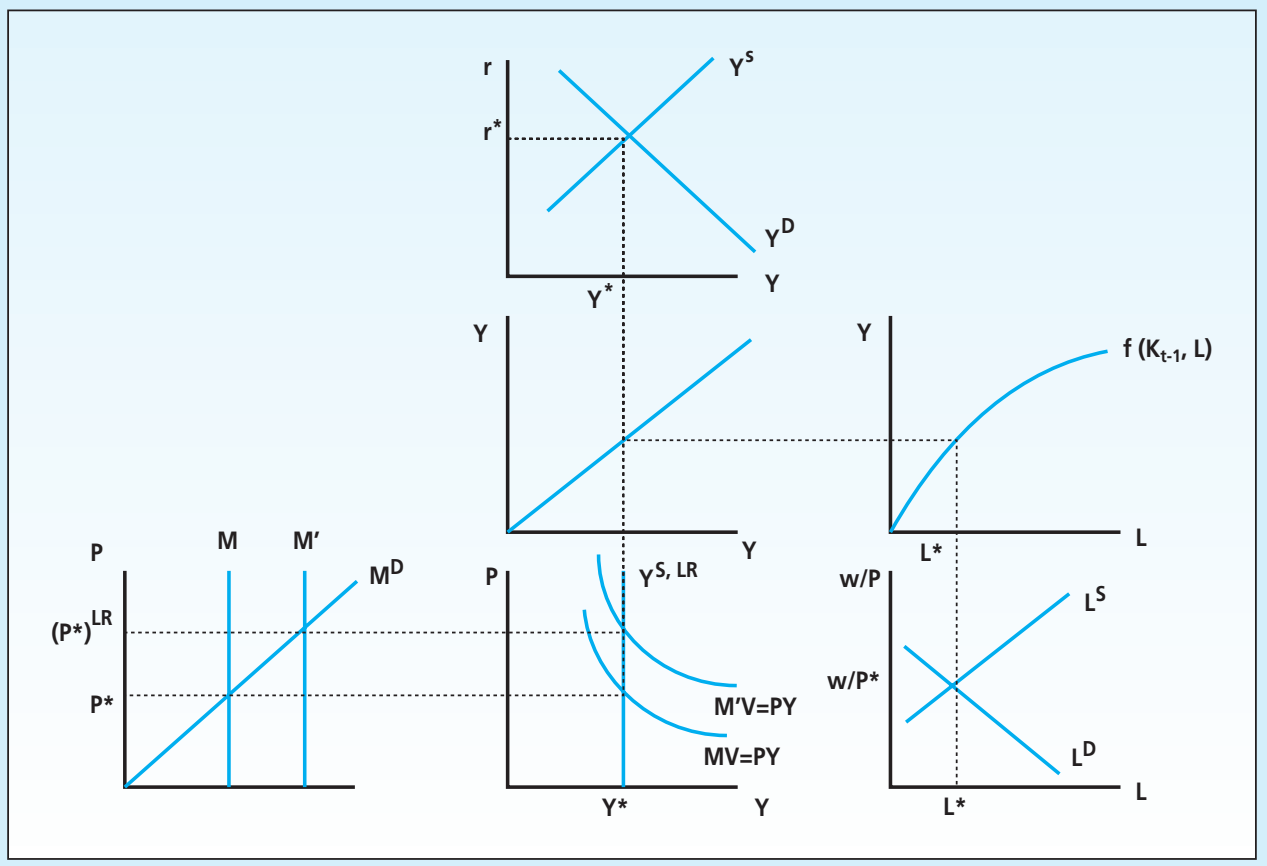

Figure 1.

Long-run Monetary Policy Effect 
change in money supply causes a change in price rate by keeping real money supply and other real variables in model fixed.

According to neoclassical model, Figure 1 shows that the increase in money supply $M$ will not make the real variables such as output $Y$ and employment opportunity $L$ change, which describes long-run money neutrality.

Figure 1 shows that the increase of the number of money $M$ to $M$ ' just increases the price $P$, meanwhile output $Y$ and employment opportunity $L$ do not change in which both of them are real variables. The situation shows the existing long-run money neutrality.

\subsection{Lucas Model}

According to this model, economy is reflected by using aggregate supply based on Lucas and monetarist aggregate demand function. Money stock follows the process of autoregressive stated in equation (8).

$$
\begin{aligned}
& y_{t}=\theta\left(p_{t}-E_{t-1} p_{t}\right), \\
& p_{t}=m_{t}-\delta y_{t}, \\
& m_{t}=\rho m_{t-1}+\varepsilon_{t}^{m} .
\end{aligned}
$$

where $y, m$, and $p$ are respectively the real output, money supply, and price in logarithm form. Money supply follows the stationary process, $(\rho \neq 1)$ and $\varepsilon^{m}$ is the shock towards money supply. Equation (8) is structural equation so that only un-anticipated changes in money supply that influences output. Thus, permanent change in the money supply does not influence the output and this situation reflects long-run money neutrality.

If equation (8) is solved for the output, then distributional lag model can be derived for money supply as in the following equation:

$$
y_{t}=\frac{\theta}{1+\theta \delta}\left(m_{t}-\rho m_{t-1}\right)
$$

Even though equation (8) shows long-run money neutrality, reduced-form provided in equation (9) shows that a permanent increase in single unit in supply stock will increase output by $\theta(1-\rho) /(1+\theta \delta)$ unit. 


\subsection{The Previous Research}

Some empirical evidences on money neutrality are study by McCandless and Weber (1995), who found a high correlation (more than 0,9) between inflation and the growth of money supply using indicator M0, M1, even M2 along 30 years in 110 countries. Instead, McCandless and Weber found the absence of correlation between the growth of money supply and the growth of real output within the same period. Meanwhile Shelley and Wallace (2003) tested the long-run money neutrality and found the money neutrality within 1932-1981 periods in Mexico. However, in 1932-2001, Shelley and Wallace using the model developed by Fisher and Seater found that there was no money neutrality regardless the size definition of money supply used. Wallace and Cabrera-Castellanos (2006) who also refer to Fisher-Seater model found the existing money neutrality in Guatemala during 1950-2002. This study found the existing M1 neutrality with GDP, expenditure, and consumption.

By using Fisher and Seater methodology, Bae and Ratti (2000) tested the existing longrun neutrality and super neutrality in Argentina and Brazil. Using low frequency data for money supply and output, this study found evidence that supports the existing hypothesis of money neutrality in Argentina and Brazil. However this research did not find the super neutrality evidence in both countries.

Some researchers, Oi et al. (2004), Chen (2007), and Puah et al. (2008) found some evidences of long-run monetary neutrality in Asian Countries. Oi et al. (2004), by using King and Watson (1997) methodology, found the long-run monetary neutrality evidence in Japan for variable M2 within 1890 - 2003 period. With the same methodology, but with quarterly data, Chen (2007) found evidence that long-run monetary neutrality M2 also occurs in South Korea within 1970.1 - 2004.4. Meanwhile Puah et al. (2008), by using Fisher-Seater methodology found the long-run monetary neutrality evidence towards M1 in some Asian countries such as Malaysia, Myanmar, Nepal, Philippine, and South Korea.

In contrast, some other researchers found different evidences which are non-neutrality of money instead. Among others, Fisher and Seater (1993) shows that M2 is not neutral in US during 1968 - 1975, Shelley and Wallace (2003) during 1932 - 2001 period in Mexico, and Ran (2005) who tested the long-run money neutrality on two exchange rate regimes in Hong Kong. Ran tested money neutrality based on Fisher and Seater model expansion (1993) and found that $\mathrm{M} 1$ is not neutral under floating exchange rate regime. With the same methodology, this empirical evidence was also found by Puah et al. (2008) that M1 is not neutral on the longrun in Indonesia during 1965 - 2002. Long-run non-neutrality evidence for M1 was also found 
by Puah in Taiwan and Thailand respectively during 1951 - 2002 and 1953 - 2002. Long-run monetary non-neutrality evidence in Taiwan was supported by Chen (2007) study using quarterly M2 data referring the method of King and Watson (1997).

Meanwhile the existing issue in terms of positive correlation between money and price was collected by, one of them, the latest study by Saatcioglu and Korap (2009) who tested money and price correlation validity based on the quantity theory of money in Turkey. The result shows that the empirical evidence supports the existing proportional relationship between money and price in Turkey's economy. Other study carried out by Roffia and Zaghini (2007) who analyzed money growth towards inflation dynamic in 15 countries. Using 3 years horizon, they found the positive correlation between aggregate monetary and price in about $50 \%$ of the observed countries. Another study is Browne and Cronin (2007) who found an empirical evidence that supports the existing correlation between price (both commodity and consumer price) and money supply in the long-run in US. Empirical result from those latest researches accorded the conclusion by Lucas (1980), Dwyer and Hafer (1988), Friedman (1992), Barro (1993), McCandless and Weber (1995), Rolnick and Weber (1997), Dewald (1998), Dwyer (1998), Dwyer and Hafer (1999), where the change of money supply has a tight correlation with the price rate.

\section{METHODOLOGY}

\subsection{Variables and Data}

On econometric analysis, we use annual data covering 1970-2008 periods. The definitions of money supply used are M1 and M2. The behavior of these two definitions of money $(\mathrm{m})$ are are important in terms of their influence on real macroeconomic variables such as output (y), beside the nominal variable such as price $(p)$. Real output is represented by real Gross Domestic Product (GDP) with year 2000 constant price, meanwhile price is represented by Consumer Price Index (CPI) with the same base year. Initial data was obtained from Indonesia Economic and Financial Statistics (SEKI), Indonesia Banking Annual Report, and Indonesia Statistics, BPS various years.

M1 is a narrow definition for money supply or money velocity. M1 includes fiat money and giral money. M2 is a wide definition for money supply that includes M1 added by near money, like savings deposit in commercial bank and time deposits. Thus fiat money added by giral money is M1, and M1 added by quasy money is M2. 


\subsection{Integrated Series and Exogeneity}

Integrated series from variables included in Fisher-Seater methodology will determine an appropriate test form. In this case, the data series of money, output, and price determine the appropriate FS test form to test long-run neutrality of money and inflation.

FS model required that in long-run neutrality test, all variables are integrated in the same order, which is assumed as I(1). In FS application, it is assumed that money, output, and price are I(1). To test integrated of order from variables used, then this research conducted unit root test through Augmented Dickey-Fuller (ADF) and Phillips-Perron (PP). ADF test is based on the following autoregressive process or $\operatorname{AR}(1)$ :

$$
y_{t}=\mu+\rho y_{t-1}+\varepsilon_{t}
$$

where $\mu$ and $\rho$ are parameters, and $\varepsilon_{t}$ is assumed as white noise. $y$ is stationary series if $-1<r$ $<1$. Dickey-Fuller test (DF) and PP use root unit as null hypotheses, $H_{0}: \rho=1$ and $H_{1}: \rho<1$. The test was done by estimating equation (10) and subtract with $y_{t-1}$ in both side of the equation would give:

$$
\Delta y_{t}=\mu+\gamma y_{t-1}+\varepsilon_{t}
$$

where, $\gamma=1-\rho$ and the null hypotheses and its alternative are:

$$
\mathrm{H}_{0}: \gamma=0 ; \mathrm{H}_{1}: \gamma<1
$$

Meanwhile Phillips and Perron (1988) proposed a non-parametric method to control high order serial correlation. PP test is a regression with $A R(1)$ process:

$$
\Delta y_{t}=\alpha+\beta y_{t-1}+\varepsilon_{t}
$$

When ADF test corrects high order serial correlation with the addition of lagged differenced terms on the right side of the equation, PP test does a t-statistic correction of coefficient $\gamma$ from $A R(1)$ regression to calculate serial correlation in $\varepsilon$. 
Furthermore, to apply FS methodology it has to fulfill the assumption that money which is M1 and M2 are exogenous. M1 and M2 are is exogenous if the variables are not influenced or caused by $y$ variable in Granger causality test on the following bivariate regression :

$$
\begin{aligned}
& y_{t}=\sum_{i=1}^{n} \alpha_{i} m_{t-i}+\sum_{j=1}^{n} \beta_{j} y_{t-j}+u_{1 t} \\
& m_{t}=\sum_{i=1}^{n} \lambda_{i} m_{t-i}+\sum_{j=1}^{n} \delta_{j} y_{t-j}+u_{2 t}
\end{aligned}
$$

where it is assumed that disturbances $u_{1}$ and $u_{2}$ are not correlated. Based on equation (14), money $(m)$ is exogenous only if the estimation result accepts $H_{0}: \delta_{j}=0$. The hypothesis interprets that output and price variables (as variable $y$ ) in the model do not influence the money $(m)$.

Test result rejects $\mathrm{H}_{0}$ if $\mathrm{F}(m, n-z)$ statistic $>F(m, n-z)$ critical value on $\alpha=5 \%$, with degree of freedom $m$ and $n-z$, where $m=$ lag sum, $n=$ number of observation, and $z=$ the number of estimated parameter. Causality test based on equation (13) and (14) for this exogeneity test refers to Hafer (1982) as expressed by Gujarati and Porter $2009^{2}$ that uses money growth

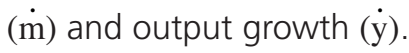

\subsection{Cointegration Test}

Cointegration test is carried out to prove the existing of long-run correlation among the estimated variables. Fisher and Seater (1993) argued that monetary neutrality would involve the existence of permanent change in money supply. In this definition, according to Engle and Granger (1987), the real and nominal variables need I(1); however both of them are not cointegrated. Cointegration test in a multivariate system uses Johansen (1995) approach based on the following formulation:

$$
\Delta Y_{t}=\Gamma_{1} \Delta Y_{t-1}+\ldots \ldots+\Gamma_{k-1} \Delta Y_{t-k+1}+\prod Y_{t-k}+\varepsilon_{t}
$$

2 See Gujarati and Porter (2009) page 699 
where $\mathrm{k}=$ number of lag. In the hypothesis test it uses the following Likelihood Ratio (LR) test statistic,

$$
Q_{r}=-T \sum_{i=r+1}^{k} \log \left(1-\lambda_{i}\right)
$$

for $\mathrm{r}=0, \ldots ., \mathrm{k}-1$ where $\lambda_{\mathrm{i}}$ is eigenvalue value. $T$ is the size of sample. $Q_{r}$ is also called trace statistic. This test rejects $\mathrm{H}_{0}$ stating there is no cointegration if $L R$ statistic > its critical value on the chosen $\alpha$.

\subsection{Fisher-Seater Methodology}

FS methodology was firstly introduced by Fisher and Seater (1993) by using bivariate system to test long-run money neutrality, where money measurement is one of the variables. Bivariate system used follows these two equations:

$$
\begin{aligned}
& a(L) \Delta^{\langle m\rangle} m_{t}=b(L) \Delta^{\langle y\rangle} y_{t}+u_{t} \\
& d(L) \Delta^{\langle y\rangle} y_{t}=c(L) \Delta^{\langle m\rangle} m_{t}+w_{t}
\end{aligned}
$$

where, $a(L), b(L), c(L)$ and $d(L)$ are lag polynomial, while $b_{0}$ and $c_{0}$ are not restricted. Error vector $\left(u_{t}, w_{t}\right) \sim \operatorname{iid}(0, \Sigma)$. In this methodology, it is assumed that $x^{t} \equiv \Delta^{i} m_{t}$ and $z^{t} \equiv \Delta^{i} m_{t}$ with $i, j=0$ or 1 . The first variable is $m$, the nominal money supply $M$ in natural logarithm. The second variable is $y$ expressing nominal and real variables in natural logarithm, like real output and price. If $m$ and $y$ variables are not integrated on the level or $\mathrm{I}(0)$ then the two variables must have the same integration order. say in first level or I(1). When variable $m$ is $\mathrm{I}(1)$, then the appropriate test is the long-run neutrality of money and inflation, and if variable $m$ is I(2), then the appropriate test is long-run super neutrality test.

Fisher and Seater defined long-run derivative (LRD) as a marginal in $z$ towards permanent change in $x$, which is written as follow:

$$
L R D_{z, x} \equiv \lim _{k \rightarrow \infty} \frac{\partial z_{t+k} / \partial u_{t}}{\partial x_{t+k} / \partial u_{t}}
$$

where $\quad \lim _{k \rightarrow \infty} \partial x_{t+k} / \partial u_{t} \neq 0$ 
Equation (19) shows that long-run derivative is the limit of output elasticity towards money. If the limit of denominator on the equation is zero, it means there is no permanent change of monetary variable, so $(m)=0$, hence we cannot do the neutrality test. For $(\mathrm{m}) \geq 1$, FS methodology shows that equation (19) can be re-written as follow:

$$
L R D_{y, m}=\frac{\left.(1-L)^{\langle m\rangle-\langle y\rangle} \gamma(L)\right|_{L=1}}{\alpha(L)}
$$

where $\alpha(L)$ and $\gamma(L)$ are function from coefficient of equation (17) and (18) which are $\alpha(L)=d(L) /$ $[a(L) c(L)-b(L) c(L)]$ and $\gamma(L)=c(L) /[a(L) c(L)-b(L) c(L)]^{3}$

Referring to Fisher and Seater, money will be neutral in the long-run (LRN) if $L R D_{y, m}=\lambda$, where $\lambda=1$ if $y$ is nominal variable, and $\lambda=0$ if $y$ is real one. Meanwhile the money will be super neutral in the long run (long-run super neutrality, $L R S N$ ) if $L R D_{y, \Delta m}=\mu$, where $\mu=1$ if $y$ is nominal variable, and $\mu=0$ if $y$ is real one.

By assuming that money supply variable are exogenous and error term $u_{t}$ and $w_{t}$ are not correlated in ARIMA model, then $c(1) / d(1)$ is Bartlett ${ }^{4}$ estimator from zero frequency in regression $\Delta^{(y)} y_{t}$ towards $\Delta^{(m)} m_{t}$. Estimation $c(1) / d(1)$ is given with $\lim _{k \rightarrow \infty} \beta_{k}$, where $\beta_{k}$ is slope coefficient from the following ordinary least squares (OLS) regression:

$$
\left[\sum_{j=0}^{k} \Delta^{\langle y\rangle} y_{t-j}\right]=\alpha_{k}+\beta_{k}\left[\sum_{j=0}^{k} \Delta^{\langle m\rangle} m_{t-j}\right]+\varepsilon_{k t}
$$

when $(m)=(y)=1$, long-run neutrality of money and inflation (LRN) can be tested and equation (21) would be:

$$
\left(y_{t}-y_{t-k-1}\right)=\alpha_{k}+\beta_{k}^{\prime}\left(m_{t}-m_{t-k-1}\right)+\mathrm{v}_{k t}
$$

The null hypothesis tests for long-run neutrality of money and inflation are $\beta_{k}$ respectively for $y$ as output and price. If the result of estimation does not reject null hypothesis then the preposition of long-run neutrality of money and inflation are empirically supported. In result

3 See Fisher and Seater (1993) page 404

4 Barlett Estimator is infinite limit of the slope coefficient. 
analysis, estimation value of $\beta_{k}$ is provided along with $95 \%$ confidence interval which is determined by standard error ${ }^{5}$ and $t$-distribution where $n / k$ is the degree of freedom for $n=$ total of observation and $k$ shows the time lag between $y$ and $m$. Because this research use annual data, then if $k=1$ it means data $y$ and $m$ are in two years difference, as well as $k=2$, 3 , and so on.

\section{RESULT AND ANALYSIS}

\subsection{Integrated Series and Exogeneity}

The following Table 1 shows that money $\left(m_{1}\right.$ and $\left.m_{2}\right)$, real output $(y)$, and price $(p)$ are not stationary on level. By taking first difference, the count ADF and PP values are smaller than their critical values, which means money variables (M1 and M2), real output (GDP), and price in the estimated model are similarly integrated or I(1).

\begin{tabular}{c|c|c|c|c|c}
\multicolumn{7}{c}{ Table 1. } \\
Variable & ADF & PP & Variable & ADF & PP \\
\hline$m_{1}$ & -2.5441 & -3.2990 & $\Delta m_{1}$ & -3.7175 & -2.9335 \\
$m_{2}$ & -1.4874 & -1.2319 & $\Delta m_{2}$ & -3.2671 & -4.4581 \\
$y$ & -1.4866 & -1.8175 & $\Delta y$ & -3.7744 & -4.2914 \\
$p$ & -1.4833 & -1.2133 & $\Delta p$ & -4.3353 & -5.5686 \\
\hline
\end{tabular}

To test long-run neutrality of money using either M1 or M2 towards output ( $y$ ) and price $(p)$, then FS methodology implementation can be done if money variable (M1 and M2), $y$ variable, and $p$ variable are similarly integrated or I(1). Because M1 and M2 are I(1) then this research is just relevant for the long-run neutrality of money test, meanwhile, long-run super neutrality for either output or price is not appropriate to be tested.

In FS methodology implementation, it is assumed that M1 and M2 variables are exogenous. Thus, this assumption has to be met before using FS methodology to test the long-run neutrality of money and inflation. The result of M1 and M2 exogeneity test through Granger causality test are based on estimation of equation (14) as reported in Table 2. The table shows that M1

5 Standard Error used is standard error from coefficient obtained from OLS estimation by considering that the number of observation is not bigger than standard error of Newey-West estimation 


\begin{tabular}{|c|c|c|c|}
\hline \multicolumn{4}{|c|}{$\begin{array}{c}\text { Table } 2 . \\
\text { Exogeneity Test Result of M1 and M2 Variables using Granger Causality }\end{array}$} \\
\hline $\mathrm{H}_{0}: \delta_{\mathrm{j}}=0$ & $F(m, n-z)$ & $\mathrm{H}_{0}: \delta_{\mathrm{j}}=0$ & $F(m, n-z)$ \\
\hline$\Delta y \rightarrow \Delta m_{1}$ & $\begin{array}{l}\mathrm{F}(1.34)=0.0863(0.7707) \\
\mathrm{F}(2.31)=0.0540(0.9476) \\
\mathrm{F}(3.28)=1.6002(0.2116) \\
\mathrm{F}(4.25)=1.1034(0.3768) \\
\mathrm{F}(5.22)=0.9874(0.4478) \\
\mathrm{F}(6.19)=0.7134(0.6433)\end{array}$ & $\Delta p \rightarrow \Delta m_{1}$ & $\begin{array}{l}\mathrm{F}(1.34)=0.0964(0.7581) \\
\mathrm{F}(2.31)=1.6492(0.2086) \\
\mathrm{F}(3.28)=2.1951(0.1108) \\
\mathrm{F}(4.25)=1.5768(0.2114) \\
\mathrm{F}(5.22)=1.2073(0.3384) \\
\mathrm{F}(6.19)=0.7550(0.6134)\end{array}$ \\
\hline$\Delta y \rightarrow \Delta m_{2}$ & $\begin{array}{l}\mathrm{F}(1.34)=5.2081(0.0289) \\
\mathrm{F}(2.31)=2.4132(0.1062) \\
\mathrm{F}(3.28)=2.6953(0.0650) \\
\mathrm{F}(4.25)=1.8704(0.1471) \\
\mathrm{F}(5.22)=1.7562(0.1638) \\
\mathrm{F}(6.19)=1.3301(0.2921)\end{array}$ & $\Delta p \rightarrow \Delta m_{2}$ & $\begin{array}{l}\mathrm{F}(1.34)=3.1158(0.0865) \\
\mathrm{F}(2.31)=1.4944(0.2401) \\
\mathrm{F}(3.28)=1.2021(0.3271) \\
\mathrm{F}(4.25)=1.2884(0.3013) \\
\mathrm{F}(5.22)=1.0044(0.4384) \\
\mathrm{F}(6.19)=1.1403(0.3775)\end{array}$ \\
\hline
\end{tabular}

Note :

Variables are in In

$\mathrm{m}=$ total lag; $\mathrm{n}=$ total observation; $\mathrm{z}=$ total estimated parameters

Numbers in parenthesis are $p$-value

variable gives strong evidence about the existing exogeneity. M1 variable is exogenous because it is not influenced by output $(y)$ and price $(p)$ variables.

Through a test with one to four lags, M1 growth variable or $\Delta m_{1}$ is not influenced by output or price growth $(\Delta y)$ since the result test accepts $\mathrm{H}_{0}: \delta_{\mathrm{j}}=0$. Meanwhile M2 variable with the same degree of freedom becomes exogenous variable when the test uses two to four lags so that the conclusion is just the same that $\mathrm{H}_{0}: \delta_{\mathrm{j}}=0$ is accepted. Test with one lag where $\alpha=$ $5 \%$ that shows that $\mathrm{H}_{0}$ is rejected or shows the existing exogeneity is the initial indicator that M2 is not neutral before being tested by using FS methodology.

\subsection{Cointegration}

The result of cointegration in Table 3 shows that nominal variable which is money and real variable are not cointegrated. Likewise that money (M1 and M2) and nominal variables (price) are not cointegrated. The left side of the table provides $L R$ statistic value as the result of cointegration test of price and money variables (M1 and M2) with four lags.

According to Johansen (1995) with assumption that data series has linier trend but cointegration equation just has intercept, which is expressed: 


\begin{tabular}{|c|c|c|c|c|c|c|c|}
\hline $\begin{array}{c}\text { Variable } \\
\text { Series }\end{array}$ & Lag & \multicolumn{2}{|c|}{ Likelihood Ratio } & Variabel & Lag & \multicolumn{2}{|c|}{ Likelihood Ratio } \\
\hline$m_{1} y$ & $\begin{array}{l}1 \\
2 \\
3 \\
4\end{array}$ & $\begin{array}{c}14.0439 \\
15.408 \\
29.4527 \\
10.5406\end{array}$ & $\begin{array}{l}4.6685 * * \\
4.8426 * * \\
4.4848 * * \\
4.1990 * *\end{array}$ & $m_{1} p$ & $\begin{array}{l}1 \\
2 \\
3 \\
4\end{array}$ & $\begin{array}{c}14.3488 \\
11.8313 \\
9.1893 \\
8.1147\end{array}$ & $\begin{array}{c}5.0122 * * \\
3.5002 \\
2.7646 \\
1.3889\end{array}$ \\
\hline$m_{2} y$ & $\begin{array}{l}1 \\
2 \\
3 \\
4\end{array}$ & $\begin{array}{c}15.1043 \\
21.5420^{*} \\
14.0283 \\
16.0130^{*}\end{array}$ & $\begin{array}{c}3.4735 \\
4.3677 * * \\
3.8209 * * \\
3.6350\end{array}$ & $m_{2} p$ & $\begin{array}{l}1 \\
2 \\
3 \\
4\end{array}$ & $\begin{array}{c}9.6757 \\
13.1000 \\
14.6110 \\
15.9431 *\end{array}$ & $\begin{array}{c}1.6400 \\
1.4894 \\
3.7128 \\
5.7769 * *\end{array}$ \\
\hline
\end{tabular}

Assumption: $\mathrm{H}_{1}(\mathrm{r}): \Pi y_{t-1}+\mathrm{B} x_{t}=\alpha\left(\beta^{\prime} y_{t-1}+\rho_{0}\right)+\alpha_{\perp} \gamma_{0}$

critical value $5 \%(r=0)=15,41$; critical value $5 \%(r \leq 1)=3,76$

*: rejects $\mathrm{H}_{0}(\mathrm{r})$ : no cointegration; **: rejects $\mathrm{H}_{0}(\mathrm{r})$ : at most one cointegration

$$
\mathrm{H}_{1}(\mathrm{r}): \Pi y_{t-1}+\mathrm{B} x_{t}=\alpha\left(\beta^{\prime} y_{t-1}+\rho_{0}\right)+\alpha_{\perp} \gamma_{0}
$$

then Table 3 shows that M1 and output are not cointegrated, so the long-run neutrality test can apply the FS methodology. At the right top of the table, it is shown that M1 and price are not cointegrated, hence the positive long-run relationship test between the variables can be applied. On the test with two and four lags for $r=0$, the result rejects the absence of cointegration between M2 and output. Likewise the test with four lags for $r=0$ and $r \leq 1$, also reject the absence of cointegration between $\mathrm{M} 2$ and price. These are actually early indication that M2 is not neutral in long-run either towards output or price.

\subsection{Long-Run Money Neutrality Test}

The result of money neutrality test of M1 using FS methodology based on equation (22) is shown in Table 4. With time difference varied from 2 years $(\mathrm{k}=1)$ until 16 years $(\mathrm{k}=15)$, the value of $\beta_{k}$ experiences an ongoing increase until 11 years even though decreased slightly for 10 years differences. For 12 years difference the $b k$ decreased but again increased again until 16 years differences. Value of $\beta_{k}$ represents the response estimated from marginal output towards marginal $\mathrm{M} 1$ on the period $k+1$. The increase of $\beta_{k}$ is also followed by its standard error $\left(S E_{k}\right)$ that lowers its $p$-value. 


\begin{tabular}{c|c|c|c|c|}
\multicolumn{5}{c}{ Table 4. } \\
\hline & The Result of Long-Run Regression of Real Output Towards M1 in Indonesia \\
\hline$k$ & $\beta k$ & $S E_{k}$ & $t_{k}$ & $p$-value \\
1 & 0.0698 & 0.0618 & 1.1293 & 0.2665 \\
2 & 0.0761 & 0.0615 & 1.2373 & 0.2244 \\
3 & 0.0920 & 0.0615 & 1.4959 & 0.1442 \\
4 & 0.1064 & 0.0616 & 1.7272 & 0.0938 \\
5 & 0.1195 & 0.0622 & 1.1921 & 0.0640 \\
6 & 0.1364 & 0.0625 & 2.1810 & 0.0372 \\
7 & 0.1531 & 0.0624 & 2.4541 & 0.0204 \\
8 & 0.1644 & 0.0625 & 2.6317 & 0.0137 \\
9 & 0.1641 & 0.0631 & 2.5982 & 0.0150 \\
10 & 0.1656 & 0.0663 & 2.4994 & 0.0191 \\
11 & 0.1556 & 0.0691 & 2.2515 & 0.0334 \\
12 & 0.1577 & 0.0714 & 2.2085 & 0.0370 \\
13 & 0.1619 & 0.0734 & 2.2069 & 0.0376 \\
14 & 0.1656 & 0.0753 & 2.1994 & 0.0387 \\
15 & 0.2021 & 0.0780 & 2.5910 & 0.0170 \\
\hline
\end{tabular}

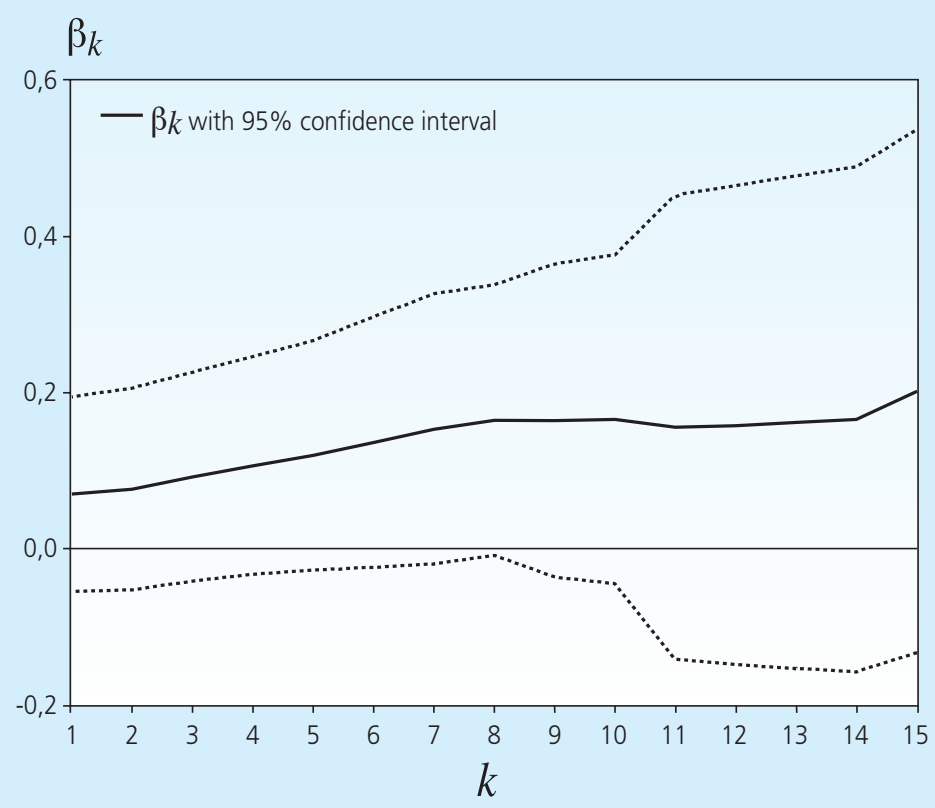

Figure 2. $\beta_{k}$ coefficient in Money Neutrality Test in Indonesia With M1 Variable. 
Table 4 shows that with $\alpha=5 \%$, money becomes no longer neutral in the long-run for more than 6 years difference. Using $\alpha=10 \%$, M1 is not neutral since 4 years difference. It proves that long-run money neutrality is not prevailed in Indonesia . In other words, the nominal money supply can influence the output in the long-run.

Figure 2 plots the coefficient b against the time differences ( $k$ values) that accord to 95\% confidence interval for estimation using M1. The figure clearly shows that M1 is not neutral along with the increase of $\beta_{k}$ and smaller standard error .

By using FS methodology, we found that money is not neutral in the long-run in Indonesia. With the same methodology, this empirical evidence is consistent to Puah et al. (2008) findings that M1 is not neutral in long-run in Indonesia during 1965 - 2002. These findings are also the same with research done by Fisher and Seater (1993) that found long run money neutrality is also rejected in US.

The evidence that long-run money neutrality is not prevailed in Indonesia is also proved for M2. Table 5 shows that by using same time difference, 2 years to 16 years, the sign of coefficient $\beta_{k}$ change from negative to positive. On 5 years difference $(k=4)$, coefficient sign changes from negative to positive and increase until 12 years difference, then decrease. Nevertheless, since 8 years difference, the coefficient $\beta_{k}$ is significant at $\alpha=5 \%$, showing that M2 is not neutral in long-run.

\begin{tabular}{c|c|c|c|c|}
\multicolumn{5}{c}{ Table 5. } \\
\hline & The Result of Long-Run Regression of Real Output Towards M2 in Indonesia \\
\hline$k$ & $\beta k$ & $S E_{k}$ & $t_{k}$ & $p$-value \\
1 & -0.0646 & 0.0732 & -0.8827 & 0.3834 \\
2 & -0.0352 & 0.0730 & -0.4816 & 0.6332 \\
3 & -0.0101 & 0.0736 & -0.1371 & 0.8918 \\
4 & 0.0250 & 0.0744 & 0.3358 & 0.7392 \\
5 & 0.0604 & 0.0751 & 0.8053 & 0.4268 \\
6 & 0.1018 & 0.0762 & 1.3360 & 0.1916 \\
7 & 0.1576 & 0.0782 & 2.0157 & 0.0532 \\
8 & 0.2143 & 0.0799 & 2.6808 & 0.0122 \\
9 & 0.2688 & 0.0798 & 3.3689 & 0.0023 \\
10 & 0.3280 & 0.0798 & 4.1102 & 0.0004 \\
11 & 0.2843 & 0.0772 & 3.6814 & 0.0011 \\
12 & 0.2633 & 0.0756 & 3.4826 & 0.0019 \\
13 & 0.2379 & 0.0772 & 3.0831 & 0.0053 \\
14 & 0.2254 & 0.0783 & 2.8769 & 0.0088 \\
15 & 0.2111 & 0.0840 & 2.5117 & 0.0203 \\
\hline
\end{tabular}


The following Figure 3 plots the coefficient $\beta$ against the time differences ( $k$ values) that accord to $95 \%$ confidence interval for estimation with M2 variable. The figure shows that M2 is also not neutral at the significant level of $\alpha=5 \%$ since 8 years difference $(k=7)$. Even it decreased in 11 years lag, $\beta_{k}$ coefficient is still significant on $\alpha=5 \%$ until the lag used is 16 years.

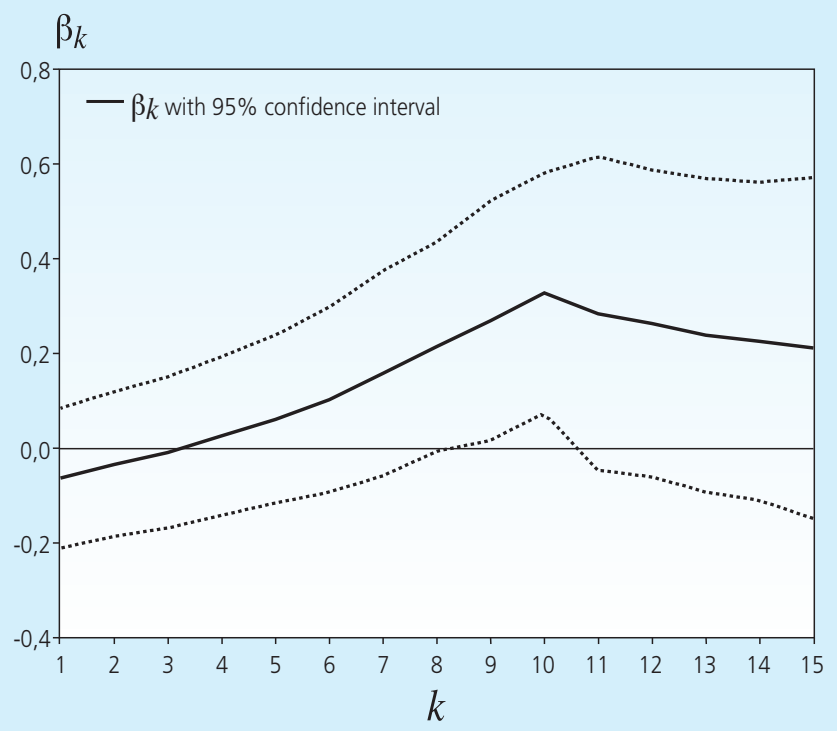

Figure 3. $\beta_{k}$ coefficient in Money Neutrality in Indonesia using $\mathrm{M} 2$ variable

Thus, either using M1 or M2, during the observation period, we have proved the empirical evidence that long-run money neutrality in Indonesia is not prevailed. The absence of money neutrality in Indonesia for either M1 or M2 variable shows this evidence is not consistent to money neutrality proposition based on neoclassical and real business cycle theory model and also monetary model from Lucas. Those theories express that money is neutral in economy that gives no influence to real variable, but just influence price rate.

\subsection{Long-Run Inflation Test}

This session provide the result test of positive long run correlation between M1 and price using FS methodology as provided earlier on equation (22), but this time with price as y variable. 
The result is shown in Table 6 . With varying the time difference for 2 years to 16 years, the value of $\beta_{k}$ is positive and significant at $\alpha=5 \%$ with the average value of $\beta_{k}$ is 0.5455 . This time, the value of $\beta_{k}$ represents estimated response from marginal price (in In) towards marginal M1 (in In) in $k+1$ period. Since 2 years difference, coefficient $\beta_{k}$ is already positive, which strongly supports the existing positive relationship between M1 and price.

\begin{tabular}{c|c|c|c|c|}
\multicolumn{5}{c}{ Table 6. } \\
The Result of Long-Run Regression of Price towards M1 in Indonesia \\
\hline$k$ & $\beta k$ & $S E_{k}$ & $t_{k}$ & $p$-value \\
1 & 0.4068 & 0.1347 & 3.0213 & 0.0047 \\
2 & 0.5550 & 0.1062 & 5.2279 & 0.0000 \\
3 & 0.5932 & 0.0956 & 6.2056 & 0.0000 \\
4 & 0.5785 & 0.0946 & 6.1145 & 0.0000 \\
5 & 0.5853 & 0.0881 & 6.6403 & 0.0000 \\
6 & 0.5750 & 0.0829 & 6.9359 & 0.0000 \\
7 & 0.5561 & 0.0868 & 6.4029 & 0.0000 \\
8 & 0.5505 & 0.0890 & 6.1865 & 0.0000 \\
9 & 0.5502 & 0.0857 & 6.4209 & 0.0000 \\
10 & 0.5309 & 0.0922 & 5.7604 & 0.0000 \\
11 & 0.5535 & 0.0983 & 5.6322 & 0.0000 \\
12 & 0.5808 & 0.0999 & 5.8143 & 0.0000 \\
13 & 0.5669 & 0.0993 & 5.7109 & 0.0000 \\
14 & 0.5216 & 0.1028 & 5.0763 & 0.0000 \\
15 & 0.4785 & 0.1086 & 4.4066 & 0.0002 \\
\end{tabular}

Table 6 shows that on $\alpha=5 \%$, money supply (with M1 variable) increases the price or inflation proportionally in the long-run. This means the nominal variable like M1 has an impact to other nominal variable, which is price that is consistent to proportion of classical quantitative theory, Lucas model, or even neoclassical model.

Figure 4 plots the coefficient $\beta$ against the year difference ( $k$ values) that is appropriate with $95 \%$ confidence interval for long-run inflation estimation by using M1. The M1 positively influences the price in long-run, regardless the choice of difference order; from 2 to 16 years.

These empirical findings are consistent to most of the previous researches by Saatcioglu and Korap (2009) in some developed countries such as Turkey, Roffia and Zaghini (2007) in 15 industrial countries, and Browne and Cronin (2007) in the US. 


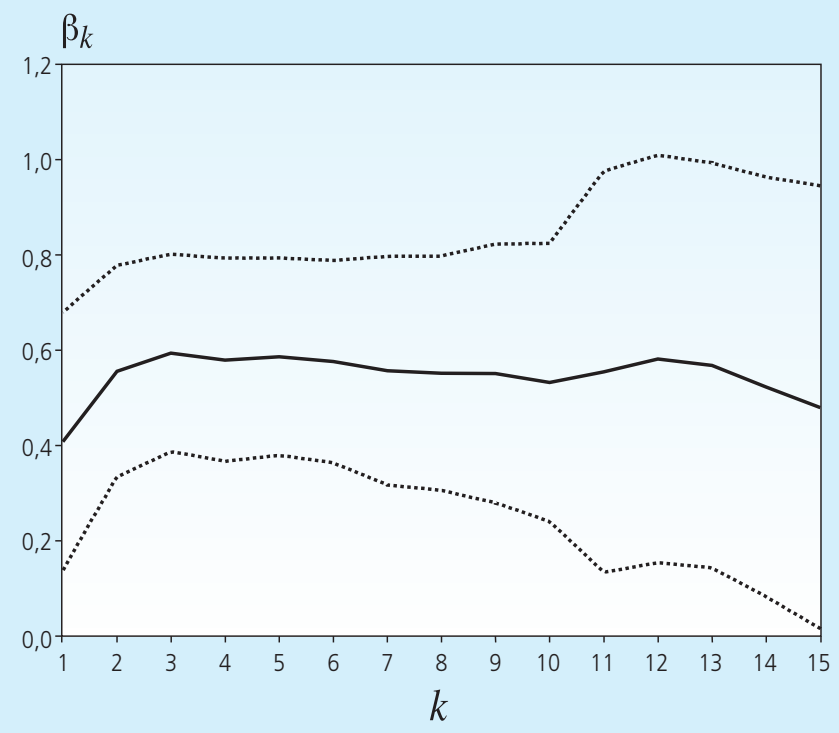

Figure 4. $\beta_{k}$ Coefficient in Long-Run Inflation Test in Indonesia with M1 Variable.

Nevertheless, the evidence of the existing positive correlation between money and price are not supported by empirically when using M2 as money supply indicator. Table 7 shows that using same range of difference order (2 to 16 years), the bk coefficient sign changes from

\begin{tabular}{|c|c|c|c|c|}
\hline$k$ & $\beta k$ & $S E_{k}$ & $t_{k}$ & p-value \\
\hline 1 & 0.4488 & 0.1609 & 2.7896 & 0.0085 \\
\hline 2 & 0.3398 & 0.1557 & 2.1820 & 0.0361 \\
\hline 3 & 0.2650 & 0.1563 & 1.6948 & 0.0995 \\
\hline 4 & 0.1923 & 0.1576 & 1.2205 & 0.2312 \\
\hline 5 & 0.1166 & 0.1567 & 0.7439 & 0.4625 \\
\hline 6 & 0.0351 & 0.1557 & 0.2251 & 0.8234 \\
\hline 7 & -0.0404 & 0.1642 & -0.2462 & 0.8072 \\
\hline 8 & -0.1111 & 0.1745 & -0.6368 & 0.5294 \\
\hline 9 & -0.2018 & 0.1793 & -1.1251 & 0.2705 \\
\hline 10 & -0.3990 & 0.1766 & -2.2598 & 0.0324 \\
\hline 11 & -0.3711 & 0.1720 & -2.1584 & 0.0407 \\
\hline 12 & -0.3535 & 0.1688 & -2.0937 & 0.0470 \\
\hline 13 & -0.3376 & 0.1605 & -2.1028 & 0.0466 \\
\hline 14 & -0.3184 & 0.1529 & -2.0821 & 0.0492 \\
\hline 15 & -0.2792 & 0.1492 & -1.8708 & 0.0754 \\
\hline
\end{tabular}




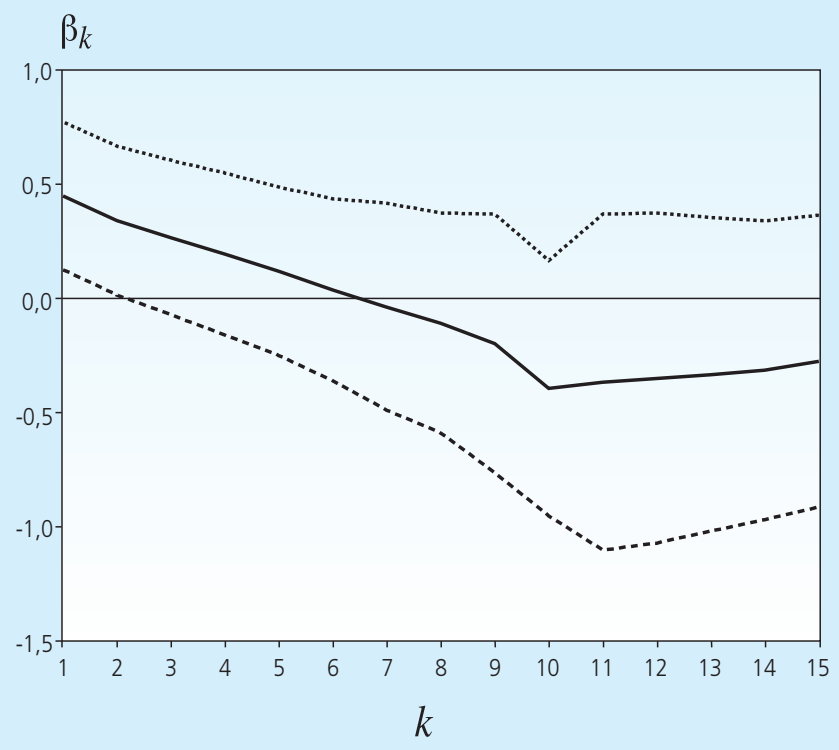

Figure 5. $\beta_{k}$ Coefficient in Long-Run Inflation Test In Indonesia using M2 Variable.

positive to negative. This sign changes occur on 8 years difference, and consistently negative until 16 years difference.

Again we have Figure 5 to plot the coefficient $\beta$ against $k$ values that accords to 95\% confidence interval for long-run inflation estimation using M2. The figure shows that M2 does not support the positive long run correlation between money and price.

\section{CONCLUSION}

This paper provides empirical estimation using FS methodology and gives conclusion that long-run neutrality of money is not prevailed in Indonesian case. In addition, this paper also proves the positive correlation between money and price only when using the narrow definition of money (M1) and not for M2.

These evidences are not consistent with the proposition of money neutrality from classical model and real business cycle model and also monetary model from Lucas.

The long-run non-neutrality of money in Indonesia confirmed in this research is consistent with Puah at al. (2008), which used different observation period, $1965-2002$. 
The implication is straightforward that monetary policy to stabilize fluctuation in macroeconomic does really matter, Monetary expansion in long-run, can stimulate the output, although it can also stimulate inflation. So, in Inflation Targeting Framework, the monetary authority can keep focusing on inflation without ignoring the importance of the role of money supply towards the long-run increase of output . 


\section{REFERENCES}

Bae, S. and R. Ratti (2000), “Long-Run Neutrality, High Inflation, and Bank Insolvencies in Argentina and Brazil," Journal of Monetary Economics, 46: 581-604.

Barro, R (1997), Macroeconomics, $5^{\text {th }}$ edition, Canbridge, MA: MIT Press.

Boschen, J.F. and C.M. Otrok (1994), "Long-Run Neutrality and Superneutrality in an ARIMA Framework: Comment," American Economic Review, 84: 1470-1473.

Browne, F. and D. Cronin (2007), "Commodity Prices, Money and Inflation," ECB Working Paper Series, 738 (March): 1-33.

Chen, S.W. (2007), "Evidence of the Long-Run Neutrality of Money: the Case of South Korea and Taiwan," Economics Bulletin, 64(3): 1-18.

Coe, P.J. and J.M. Nason (2004), "Long-Run Monetary Neutrality and Long-Horizon Regressions, " Journal of Applied Econometrics, 19 (3): 355-373

Dickey, D. and W.A. Fuller (1979), "Distribution of the Estimates for Autoregressive Time Series with a Unit Root," Journal of the American Statistical Society, 74: 427-431.

Dewald, W.G. (1998), "Historical U.S. Money Growth, Inflation, and Inflation Credibility," Federal Reserve Bank of St. Louis Review, 80:13-24.

Dwyer, G.P. and R. W. Hafer (1999), "Are Money Growth and Inflation Still Related?," Federal Reserve Bank of Atlanta Economic Review, Second Quarter: 32-43.

Engle, R.F. and C.W.J. Granger (1987), "Cointegration and Error Correction: Representation, Estimation and Testing," In Engle R.F. and C.W.J. Granger (1991), Long-Run Economic Relationships: Readings in Cointegration, 81-111. New York: Oxford University Press.

Fisher, M.E and J.J. Seater (1993), "Long-Run Neutrality and Superneutrality in an ARIMA Framework," American Economic Review, 83(3): 402-415.

Gujarati, D.N. and D.C. Porter (2009), Basic Econometrics, $5^{\text {th }}$ Edition, New York: McGraw-Hill. Hume, D. (1752), "Of Money, Of Interest, and Of the Balance of Trade," In Essays, Moral,

Political, and Literary, Reprinted in Hume, 1955, Writings on Economics, Eugene Rotwein ed.

Diakses dari http://www.econlib.org/library/LFBooks/Hume/hmMPL.html Johansen, S. (1995), Likelihood-based Inference in Cointegrated Vector Autoregressive Models, New York: Oxford University Press. 
King, R.G. and M.W. Watson (1997), "Testing Long-Run Neutrality," Federal Reserve Bank of Richmond Economic Quarterly, 83(3): 69-101.

Lucas, R.E. (1972), "Expectations and the Neutrality of Money," Journal of Economic Theory, 4(2): 103-124.

(1980), "Two Illustrations of the Quantity Theory of Money," American Economic Review, 70: 1005-1014.

(1995), "Monetary Neutrality. Prize Lecture," December 7, 1995. Diakses dari http:/ /nobelprize.org/economics/laureates/1995/lucas-lecture.pdf.

McCandless, G.T., Jr. and W.E. Weber (1995), "Some Monetary Facts," Federal Reserve Bank of Minneapolis Quarterly Review, 19(3): 1-11.

Noriega, A.E (2004), "Long-Run Monetary Neutrality and the Unit-Root Hypothesis: Further International Evidence," North American Journal of Economics and Finance, 15(2): 179197.

Noriega, A.E., L.M. Soria and R. Velazquez (2005), "International Evidence on Monetary Neutrality under Broken Trend Stationary Models," Mimeo. Diakses dari http://repec.org/esLATM04/ up.7482.1080751251.pdf

Oi, H., S. Shiratsuka, and T. Shirota (2004), "On Long-Run Monetary Neutrality in Japan," Monetary and Economic Studies, 22(3): 79 - 113

Olekalns, N. (1996), "Some Further Evidence on the Long-Run Neutrality of Money, " Economics Letters, 50(3): 393-98.

Phillips, P.C.B., and P. Perron (1988), "Testing for a Unit Root in Time Series Regression," Biometrika, 75(2): 335-346.

Puah, C.H., M.S. Habibullah and S.A. Mansor (2008), "On the Long-Run Monetary Neutrality: Evidence from the SEACEN Countries," Journal of Money, Investment and Banking, Issue 2: 50-62.

Ran, J. (2005), "Is There Long-Run Money Neutrality under Different Exchange Rate Regimes?," Pacific Economic Review, 10(3): 361-370.

Roffia, B. and A. Zaghini (2007), " Excess Money Growth and Inflation Dynamics, " ECB Working Paper Series, 749: 1-40.

Romer, D. (2001), Advanced Macroeconomics, Second Edition, New York: McGraw-Hill. Rolnick, A.J. and W.E. Weber (1997), "Inflation, Money, and Output under Alternative Monetary Standards," Federal Reserve Bank of Minneapolis Research Department, Staff Report 175. Saatcioglu, C. and L. Korap (2009), "The Search for Co-Integration Between Money, Prices and Income: Low Frequency Evidence from the Turkish Economy," Panoeconomicus, 1: 55-72. Serletis, A. and Z. Koustas (1998), "International Evidence on the Neutrality of Money," Journal of Money, Credit and Banking, 30 (1): 1-25. 
— Inquiry, 39 (1): 124-138. Diakses dari http://econpapers.repec.org/article/oupecinqu/ Shelley, G.L. and F.H. Wallace (2003), "Testing for Long Run Neutrality of Money in Mexico," Diakses dari http://129.3.20.41/eps/mac/papers/0402/0402003.pdf

Wallace, F.H. and L.F. Cabrera-Castellanos (2006), "Long Run Money Neutrality in Guatemala," MPRA Paper 4025, University Library of Munich, Germany, revised 2006. Diakses dari http:/ 1129.3.20.41/eps/mac/papers/ 
100 Bulletin of Monetary, Economics and Banking, July 2011

This page is intentionally left blank 